\title{
Long-term tendencies in climate change of the Urals due to global warming
}

\author{
A.A. Vasiliev*, L.V. Ufimtseva, N.V. Glaz, and D.Yu. Nokhrin
}

Ural Federal Agrarian Research Center of the Ural Branch of the Russian Academy of Sciences, st. Belinsky, 112a, 620142 Yekaterinburg, Russia

\begin{abstract}
During the observation period, the annual air temperature increased: in Yekaterinburg (1832-2018) by $3,1^{\circ} \mathrm{C}$, in Zlatoust (1881-2018) by $2,2^{\circ} \mathrm{C}$, in Kurgan $(1894-2018)$ by $2,2^{\circ} \mathrm{C}$ and in Shadrinsk (1894-2018) by $2,1^{\circ} \mathrm{C}$. The analogical climate change was noted for the period $1966-$ 2018. The strongest warming is observed in winter (by $2,3-3,0^{\circ} \mathrm{C}$ ), the weakest warming is observed in spring (by $0,8-1,7^{\circ} \mathrm{C}$ ). We noted an increase the annual amount of precipitation in Ivdel (by 68,2 $\mathrm{mm}$ ), Shadrinsk (by $50,9 \mathrm{~mm}$ ) and Krasnoufimsk (by 43,6 mm). Also marked an increase the amount of precipitation during the growing season in Ivdel (by $43,9 \mathrm{~mm}$ ), Shadrinsk (by 42,8 $\mathrm{mm}$ ) and Krasnoufimsk (by $26,8 \mathrm{~mm}$ ). The annual amount of precipitation increased in Chelyabinsk and Yekaterinburg, but the amount of precipitation during the growing season decreased in Kurgan. Favorable changes in the agro-climatic conditions of growing season were noted in Shadrinsk and Zlatoust. Unfavorable changes in hydrothermal coefficient for cultivated plants were noted in Chelyabinsk, Kurgan, Troitsk, Yekaterinburg and Bredy. Identified the need to introduce an irrigation system for cultivated plants of the southern districts (Chelyabinsk region).
\end{abstract}

\section{Introduction}

Global climate change is the most important scientific problem of the modern era, which determines the survival of human civilization [1-3]. According to the World Meteorological Organization from 1850 to 2009 the average global temperature on Earth increased by $0.88^{\circ} \mathrm{C}$ [4]. Numerous studies show that agriculture is significantly affected by ongoing climate change. Global warming significantly affects the agro-climatic potential of agroecosystems [5-6], the phytosanitary state of agrophytocenoses [7-9], the physical and agrochemical properties of the soil [10-13], the efficiency of fertilizers [14], and the stability of agricultural production [15-17]. Global climate change can have a multidirectional impact on agricultural production, and therefore falls within the sphere of interests of agricultural science. Identify patterns in changes of the local climate we can develop a set of measures and minimize possible damage of the agro-industrial complex [1, $18]$.

\footnotetext{
*Corresponding author: kartofel_chel@mail.ru
} 
The aim of the research was to identify long-term tendencies in climate change of the Urals (the largest industrial and agricultural region of Russia).

\section{Materials and methods}

The object of research is a complex of meteorological data from the Chelyabinsk weather station and the time series of All-Russia Research Institute of Hydrometeorological Information - World Data Centre [19-21]. When analyzing changes in air temperature and the amount of precipitation, special attention was paid to the period from 1966 to 2019.

Data processing and identification of patterns in the dynamics of the studied climatic indicators were carried out using the standard Excel package and dynamic modeling methods [22].

\section{Results and discussion}

The longest series of observations in the Urals is available at the Yekaterinburg weather station (since 1832). The average annual air temperature here in the XIX century averaged $0,6^{\circ} \mathrm{C}$, in the first half of the XX century $-1,3^{\circ} \mathrm{C}$, in the second half of the XX century $2,3^{\circ} \mathrm{C}$, and at the beginning of the XXI century $-3,4^{\circ} \mathrm{C}$ (Fig. 1).

In analyze the average annual air temperatures by the direct trunk function method, it was found that global warming significantly affect at the agro-climatic conditions of the Urals. The air temperature increased: in Yekaterinburg (1832-2018) by $3,1^{\circ} \mathrm{C}$, in Zlatoust (1881-2018) by $2,2^{\circ} \mathrm{C}$, in Kurgan (1894-2018) by 2,2 and in Shadrinsk (1894-2018) - by $2,1^{\circ} \mathrm{C}$. In the $\mathrm{XX}$ century in points of meteorological observations the greatest warming was noted in Bredy $(1940-2018)$ by $2,6^{\circ} \mathrm{C}$, in Troitsk $(1940-2018)$ by $2,3^{\circ} \mathrm{C}$ and in Chelyabinsk (1951-2019) by $2,0^{\circ} \mathrm{C}$; the lowest warming was noted in Ivdel (1935-2018) by $1,1^{\circ} \mathrm{C}$ and in Krasnoufimsk (1926-2018) by $1,3^{\circ} \mathrm{C}$.

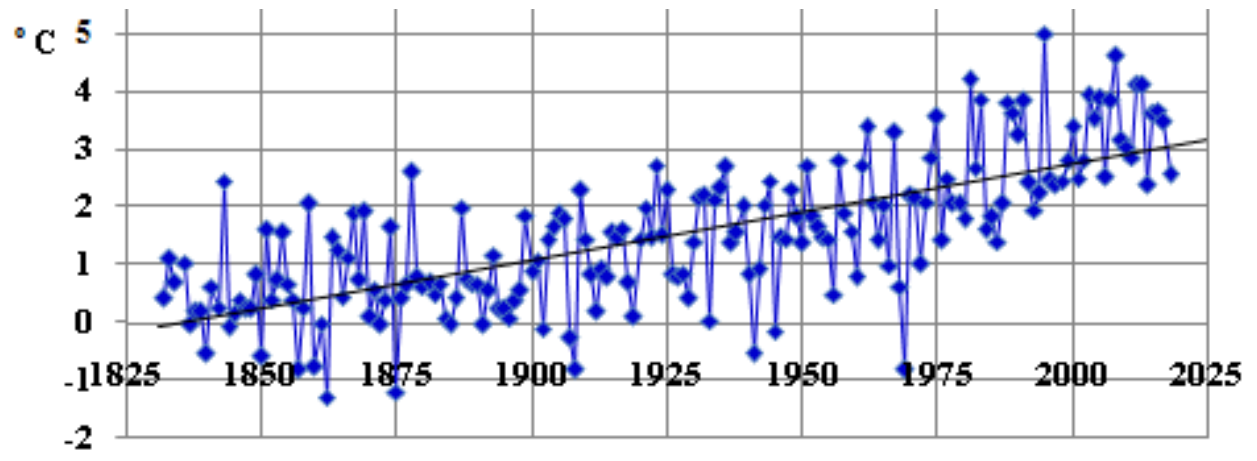

Fig. 1. Dynamics of the average annual air temperature in Yekaterinburg (1832-2018)

Analysis of meteorological characteristics for 9 stations from 1966 to 2018 showed that the process of climate change of the Urals is heterogeneous. The average annual temperature increase uniformly $\left(1,6-2,0^{\circ} \mathrm{C}\right)$. The annual amount of precipitation growing in Ivdel, Yekaterinburg, Shadrinsk and Krasnoufimsk (by 43,6-68,2 mm); slowly increasing in Chelyabinsk (by 32,8 mm); decreasing in Troitsk (by 9,6 mm), Bredy (by 29,5 mm) and Zlatoust (by $65 \mathrm{~mm}$ ) and not changing in Kurgan $(2,6 \mathrm{~mm})$ (Table 1).

During the growing season (from May to September) 1966-2018 the temperature increased: in Yekaterinburg by $2,0^{\circ} \mathrm{C}$, in Ivdel by $1,7^{\circ} \mathrm{C}$, in Chelyabinsk - by $1,7^{\circ} \mathrm{C}$, in Zlatoust $1,6^{\circ} \mathrm{C}$, in Bredy - by $1,6^{\circ} \mathrm{C}$, in Kurgan by $1,4^{\circ} \mathrm{C}$, in Troitsk by $1,4^{\circ} \mathrm{C}$, in 
Shadrinsk by $1,3^{\circ} \mathrm{C}$, in Krasnoufimsk by $1,2^{\circ} \mathrm{C}$. The amount of precipitation increase in Ivdel (by 43,9 mm), Shadrinsk (by 42,8 $\mathrm{mm}$ ) and Krasnoufimsk (by 26,8 $\mathrm{mm}$ ). The amount of precipitation decrease in other points.

The amount of precipitation during the growing season decrease in Zlatoust (mountain-forest zone of the Chelyabinsk region) by $48,7 \mathrm{~mm}$ and Bredy (steppe zone of the Chelyabinsk region) by $45,5 \mathrm{~mm}$. The amount of precipitation during the growing season slightly decrease in Troitsk (by 22,7 mm), Kurgan (by 13,7 mm), Yekaterinburg (by $0,1 \mathrm{~mm}$ ) and Chelyabinsk (by $3,2 \mathrm{~mm}$ ).

The strongest warming in the Urals is observed in February (by $3,0^{\circ} \mathrm{C}$ ), January (by $2,8^{\circ} \mathrm{C}$ ), October (by $2,6^{\circ} \mathrm{C}$ ), December (by $2,2^{\circ} \mathrm{C}$ ), August (by $2,1^{\circ} \mathrm{C}$ ) and June (by $2,0^{\circ} \mathrm{C}$ ); the weakest warming is observed in April $\left(0,4^{\circ} \mathrm{C}\right)$, July $\left(0,8^{\circ} \mathrm{C}\right)$, November $\left(0,8^{\circ} \mathrm{C}\right)$ and September $\left(1,3^{\circ} \mathrm{C}\right)$. The average annual air temperature increased in March $\left(1,9^{\circ} \mathrm{C}\right)$ and May $\left(1,6^{\circ} \mathrm{C}\right)$ (Table 2$)$.

Table 1. Change in air temperature and the amount of precipitation of the Urals for 1966-2018

\begin{tabular}{|l|c|c|c|c|c|c|}
\hline \multirow{2}{*}{ Weather station } & \multicolumn{7}{|c|}{ Air temperature, ${ }^{\circ} \mathrm{C}$} & \multicolumn{3}{c|}{ Amount of precipitation, $\mathrm{mm}$} \\
\cline { 2 - 7 } & $\mathrm{Y}_{\mathrm{o}}$ & $\mathrm{Y}_{\mathrm{t}}$ & trend & $\mathrm{Y}_{\mathrm{o}}$ & $\mathrm{Y}_{\mathrm{t}}$ & trend \\
\hline \multicolumn{7}{|c|}{ Per year } \\
\hline Shadrinsk & 1,8 & 3,5 & 1,7 & 427,2 & 478,1 & 50,9 \\
\hline Kurgan & 1,4 & 3,3 & 1,9 & 384,7 & 387,3 & 2,6 \\
\hline Ivdel & $-1,1$ & 0,7 & 1,8 & 499,2 & 567,4 & 68,2 \\
\hline Krasnoufimsk & 0,9 & 2,7 & 1,8 & 540,2 & 583,8 & 43,6 \\
\hline Yekaterinburg & 1,7 & 3,7 & 2,0 & 489,9 & 540,8 & 50,9 \\
\hline Zlatoust & 0,8 & 2,4 & 1,6 & 722,9 & 657,9 & $-65,0$ \\
\hline Chelyabinsk & 1,8 & 3,7 & 1,9 & 438,4 & 471,2 & 32,8 \\
\hline Troitsk & 2,3 & 3,9 & 1,6 & 387,4 & 377,8 & $-9,6$ \\
\hline Bredy & 2,0 & 3,8 & 1,8 & 370,1 & 340,6 & $-29,5$ \\
\hline \multicolumn{7}{|c|}{ Durnyyyyyyyyyy} \\
\hline Shadrinsk & 14,6 & 15,9 & 1,3 & 263,1 & 305,9 & 42,8 \\
\hline Kurgan & 15,0 & 16,4 & 1,4 & 243,3 & 229,6 & $-13,7$ \\
\hline Ivdel & 11,5 & 13,2 & 1,7 & 315,6 & 359,5 & 43,9 \\
\hline Krasnoufimsk & 13,4 & 14,6 & 1,2 & 300,5 & 327,4 & 26,8 \\
\hline Yekaterinburg & 13,5 & 15,5 & 2,0 & 325,2 & 325,3 & 0,1 \\
\hline Zlatoust & 12,2 & 13,8 & 1,6 & 426,5 & 377,8 & $-48,7$ \\
\hline Chelyabinsk & 14,6 & 16,3 & 1,7 & 281,9 & 285,2 & 3,2 \\
\hline Troitsk & 15,6 & 17,0 & 1,4 & 238,2 & 215,5 & $-22,7$ \\
\hline Bredy & 15,7 & 17,3 & 1,6 & 208,9 & 163,3 & $-45,5$ \\
\hline
\end{tabular}

Table 2. Monthly tendencies in air temperature of the Urals for 1966-2018

\begin{tabular}{|c|c|c|c|c|c|c|c|c|c|}
\hline $\begin{array}{l}\text { Month, } \\
\text { season }\end{array}$ & 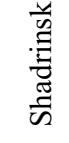 & 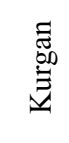 & $\frac{\bar{\theta}}{\vec{D}}$ & 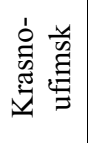 & 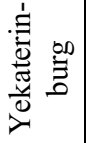 & $\begin{array}{l}\vec{y} \\
\overrightarrow{0} \\
\frac{\vec{\pi}}{N}\end{array}$ & 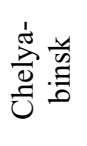 & 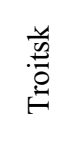 & 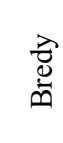 \\
\hline January & 2,7 & 2,7 & 2,7 & 3,1 & 3,1 & 2,8 & 2,9 & 2,6 & 2,9 \\
\hline February & 3,2 & 3,4 & 3,6 & 2,8 & 3,4 & 3,1 & 2,9 & 2,3 & 2,6 \\
\hline Март & 2,1 & 3,0 & 0,6 & 1,6 & 1,3 & 1,4 & 2,7 & 1,8 & 2,3 \\
\hline April & 0,6 & 0,8 & 0,9 & 0,4 & 0,2 & $-0,4$ & 0,5 & 0,2 & 0,6 \\
\hline May & 1,6 & 1,7 & 2,5 & 1,3 & 2,2 & 1,3 & 1,8 & 1,1 & 0,9 \\
\hline
\end{tabular}


Table 2. Continued

\begin{tabular}{|c|c|c|c|c|c|c|c|c|c|}
\hline June & 1,8 & 2,1 & 2,4 & 1,4 & 2,4 & 1,8 & 2,0 & 1,9 & 1,8 \\
\hline July & 0,2 & 0,1 & 1,1 & 0,6 & 1,3 & 1,2 & 1,2 & 0,6 & 0,8 \\
\hline August & 2,0 & 2,1 & 1,3 & 1,6 & 2,5 & 2,5 & 2,3 & 2,2 & 2,8 \\
\hline September & 0,9 & 1,1 & 1,3 & 1,2 & 1,7 & 1,5 & 1,1 & 1,2 & 1,5 \\
\hline October & 2,5 & 2,5 & 3,6 & 2,4 & 2,7 & 2,3 & 2,8 & 2,3 & 2,6 \\
\hline November & 0,8 & 1,2 & 0,1 & 0,8 & 0,4 & 0,4 & 1,2 & 1,3 & 1,2 \\
\hline December & 2,2 & 2,5 & 1,7 & 2,5 & 2,5 & 1,7 & 2,9 & 2,1 & 2,0 \\
\hline Winter & $\mathbf{2 , 7}$ & $\mathbf{2 , 8}$ & $\mathbf{2 , 7}$ & $\mathbf{2 , 8}$ & $\mathbf{3 , 0}$ & $\mathbf{2 , 6}$ & $\mathbf{2 , 9}$ & $\mathbf{2 , 3}$ & $\mathbf{2 , 5}$ \\
\hline Spring & $\mathbf{1 , 5}$ & $\mathbf{1 , 8}$ & $\mathbf{1 , 3}$ & $\mathbf{1 , 1}$ & $\mathbf{1 , 3}$ & $\mathbf{0 , 8}$ & $\mathbf{1 , 7}$ & $\mathbf{1 , 0}$ & $\mathbf{1 , 3}$ \\
\hline Summer & $\mathbf{1 , 3}$ & $\mathbf{1 , 5}$ & $\mathbf{1 , 6}$ & $\mathbf{1 , 2}$ & $\mathbf{2 , 1}$ & $\mathbf{1 , 8}$ & $\mathbf{1 , 8}$ & $\mathbf{1 , 6}$ & $\mathbf{1 , 8}$ \\
\hline Autumn & $\mathbf{1 , 4}$ & $\mathbf{1 , 6}$ & $\mathbf{1 , 7}$ & $\mathbf{1 , 4}$ & $\mathbf{1 , 6}$ & $\mathbf{1 , 4}$ & $\mathbf{1 , 7}$ & $\mathbf{1 , 6}$ & $\mathbf{1 , 8}$ \\
\hline
\end{tabular}

The strongest climate warming is observed in winter (by $2,3-3,0^{\circ} \mathrm{C}$ ). The spring period has a less warming in the most zones (by $0,8-1,7^{\circ} \mathrm{C}$ ). In Shadrinsk and Kurgan the summer period has a less warming (by $1,3-1,5^{\circ} \mathrm{C}$ ).

At the Ural region amount of spring precipitation increase: in the Sverdlovsk region (by $35,4-47,1 \mathrm{~mm}$ ), in Chelyabinsk (by 23,8-26,3 mm), in Bredy (by 23,8-26,3 mm), in Kurgan (by 14,4-18,3 mm), in Shadrinsk (by 14,4-18,3 mm), in Zlatoust (by 5,9-8,8 mm), in Troitsk (by 5,9-8,8 mm) (Table 3). The amount of summer precipitation decrease: in Bredy by $50,8 \mathrm{~mm}$, in Zlatoust by $41,4 \mathrm{~mm}$, in Troitsk by $17,1 \mathrm{~mm}$, in Kurgan by $15,8 \mathrm{~mm}$, in Yekaterinburg by $8,2 \mathrm{~mm}$. The amount of summer precipitation increased only in Shadrinsk (by $22,1 \mathrm{~mm}$ ). The amount of summer precipitation changed insignificantly in Ivdel (by 3,7 $\mathrm{mm}$ ) and in Chelyabinsk (by $-1,1 \mathrm{~mm}$ ).

Table 3. Monthly trends in the amount of precipitation of the Urals for 1966-2018

\begin{tabular}{|c|c|c|c|c|c|c|c|c|c|}
\hline $\begin{array}{l}\text { Month, } \\
\text { season }\end{array}$ & 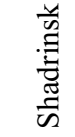 & 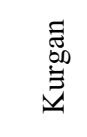 & $\vec{D}$ & 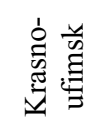 & 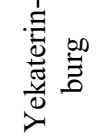 & $\begin{array}{l}\vec{n} \\
\overrightarrow{0} \\
\frac{\vec{J}}{N}\end{array}$ & 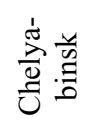 & $\begin{array}{l}\frac{y}{\tilde{n}} \\
\stackrel{0}{0} \\
\stackrel{0}{*}\end{array}$ & 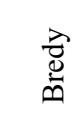 \\
\hline January & $-1,6$ & $-0,2$ & 1,3 & $-2,7$ & 5,0 & $-11,4$ & $-0,2$ & 2,7 & $-1,6$ \\
\hline February & $-6,3$ & $-2,5$ & 2,8 & $-4,4$ & $-5,5$ & $-10,5$ & 0,5 & 2,1 & 8,8 \\
\hline Mapт & 13,2 & 8,2 & 13,9 & 13,5 & 15,2 & 1,9 & 16,2 & 12,6 & 12,3 \\
\hline April & $-2,8$ & $-0,7$ & 14,3 & 9,7 & 26,2 & $-1,6$ & 6,2 & $-3,0$ & $-1,6$ \\
\hline May & 8,0 & 6,9 & 9,3 & 12,2 & 5,6 & 5,5 & 1,4 & $-0,8$ & 15,7 \\
\hline June & $-0,2$ & $-19,1$ & 37,5 & 15,2 & $-0,7$ & $-10,0$ & 3,7 & $-3,0$ & $-22,7$ \\
\hline July & 8,5 & 6,4 & $-24,0$ & $-15,2$ & $-12,6$ & $-35,1$ & $-6,8$ & $-31,0$ & $-24,2$ \\
\hline August & 13,8 & $-3,1$ & $-9,8$ & 14,9 & 5,1 & 3,7 & 2,0 & 17,0 & $-4,0$ \\
\hline September & 12,2 & $-4,8$ & 30,9 & $-0,3$ & 2,7 & $-12,8$ & 2,9 & $-4,8$ & $-10,4$ \\
\hline October & $-1,3$ & 1,7 & $-4,8$ & $-1,0$ & 3,1 & 12,8 & 5,6 & $-5,7$ & $-1,2$ \\
\hline November & 6,3 & 6,7 & 0,6 & $-1,7$ & 9,2 & $-5,1$ & 4,2 & 1,3 & 2,3 \\
\hline December & 0,9 & 3,0 & $-3,7$ & 10,4 & 6,5 & $-2,6$ & $-2,9$ & 2,0 & $-3,0$ \\
\hline Winter & $-7,1$ & 0,4 & 0,4 & 3,3 & 6,1 & $-24,5$ & $-2,7$ & 6,9 & 4,2 \\
\hline Spring & 18,3 & 14,4 & 37,4 & 35,4 & 47,1 & 5,9 & 23,8 & $\begin{array}{l}8,8 \\
\end{array}$ & 26,3 \\
\hline Summer & 22,1 & $-15,8$ & 3,7 & 14,9 & $-8,2$ & $-41,4$ & $-1,1$ & $-17,1$ & $-50,8$ \\
\hline Autumn & 17,1 & 3,7 & 26,7 & $-3,0$ & 15,0 & $-5,1$ & 12,7 & $-9,3$ & $-9,3$ \\
\hline
\end{tabular}

The most important integral indicator for assessing the agro-climatic conditions of the region is Selyaninov's hydrothermal coefficient (HTC). For 1966-2018 the HTC of the growing season decreased in Ivdel by 0,02 ; in Chelyabinsk by 0,12 ; in Kurgan by 0,14 ; in Troitsk by 0,17 ; in Yekaterinburg by 0,20 ; in Bredy by 0,25 and in Zlatoust by 0,50 units. The HTC for the analyzed period in Krasnoufimsk did not change, in Shadrinsk increased by 0,08 units. These changes should be considered positive only in Zlatoust (since the 
growing season ceased to be excessively wet and the HTC decreased from 2,29 to 1,79) and in Shadrinsk (it became rather wet and HTC increased from 1,18 to 1,26). A deterioration in conditions for the cultivated plants is noted in Chelyabinsk, Kurgan, Troitsk and Bredy. In the steppe zone of the Chelyabinsk region (where the HTC decreased from 0,87 to 0,62 ) it becomes impossible to obtain the harvests without irrigation. In Yekaterinburg, changes in agro-climatic conditions are not catastrophic yet (Figure 2).
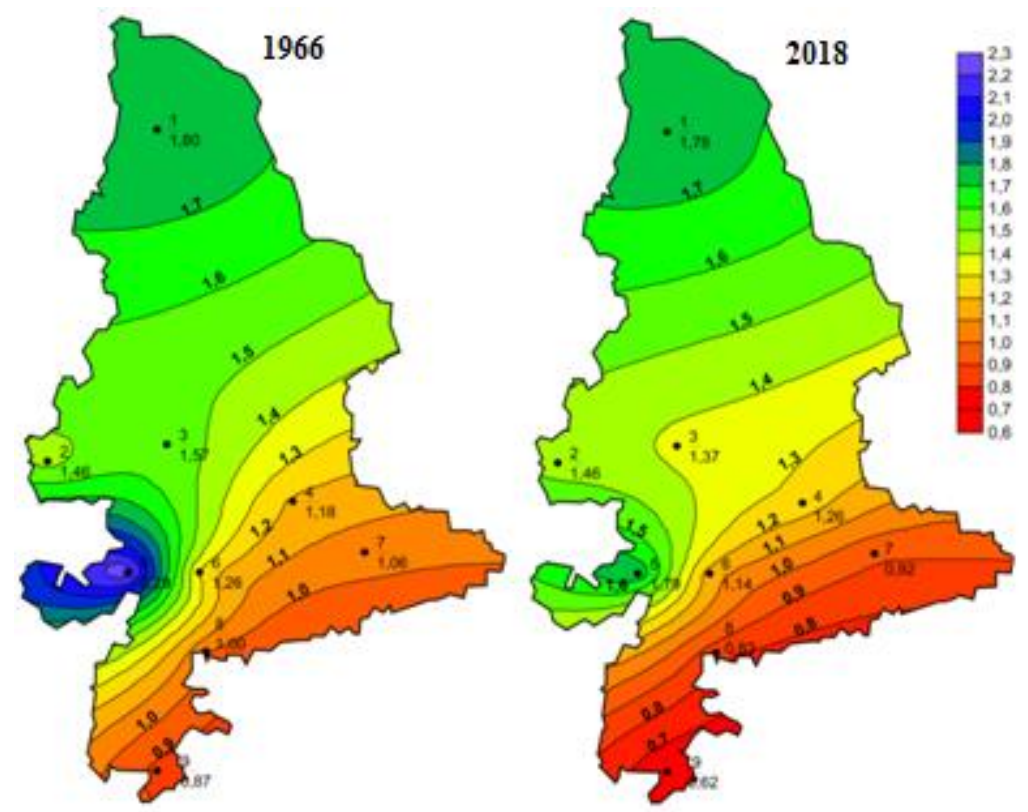

Fig. 2. Hydrothermal coefficient of the Urals (at the beginning and at the end of the analyzed period): 1 - Ivdel, 2 - Krasnoufimsk, 3 - Yekaterinburg, 4 - Shadrinsk, 5 - Zlatoust, 6 - Chelyabinsk, 7 Kurgan, 8 - Troitsk, 9 - Bredy

\section{Conclusions}

1. Global warming significantly affects at the climate of the Ural region. The increase in the average annual air temperature in the Sverdlovsk, Kurgan and Chelyabinsk regions occurs evenly over the period $1966-2018$ (by $1,6-2,0^{\circ} \mathrm{C}$ ). The annual precipitation increase in Ivdel (by $68 \mathrm{~mm}$ ), in Yekaterinburg (by 50,9 mm), in Shadrinsk (by 50,9 $\mathrm{mm}$ ), in Krasnoufimsk (by 43,6 mm) and in Chelyabinsk (by $32,8 \mathrm{~mm}$ ). The annual precipitation did not change in Kurgan and decreased in Zlatoust (by 68,2 mm), in Troitsk (by 9,6 mm) and in Bredy (by 29,5 mm).

2. Temperature of the growing season (from May to September) during 1966-2018 increased in Yekaterinburg by $2,0^{\circ} \mathrm{C}$, in Ivdel by $1,7^{\circ} \mathrm{C}$, in Chelyabinsk by $1,7^{\circ} \mathrm{C}$, in Zlatoust by $1,6^{\circ} \mathrm{C}$, in Bredy by $1,6^{\circ} \mathrm{C}$, in Kurgan by $1,4^{\circ} \mathrm{C}$, in Troitsk by $1,4^{\circ} \mathrm{C}$, in Shadrinsk by $1.3^{\circ} \mathrm{C}$, in Krasnoufimsk by $1,2^{\circ} \mathrm{C}$. The amount of precipitation during the growing season increase in the Sverdlovsk region and northwestern zones of the Kurgan region. The amount of precipitation during the growing season decrease in Zlatoust by 48,7 $\mathrm{mm}$, in Bredy by $45,5 \mathrm{~mm}$ and in Troitsk by $22,7 \mathrm{~mm}$ (Chelyabinsk region).

3. The greatest warming is noted in the winter period (by $2,3-3,0^{\circ} \mathrm{C}$ ). The amount of spring precipitation of the Ural region increase during the analyzed period: in the Sverdlovsk region by 35,4-47,1 mm, in Chelyabinsk by 23,8-26,3 mm, in Bredy by 23,8$26,3 \mathrm{~mm}$, in Kurgan by $14,4-18,3 \mathrm{~mm}$, in Shadrinsk by $14,4-18,3 \mathrm{~mm}$, in Zlatoust by $5,9-$ 
$8,8 \mathrm{~mm}$, in Troitsk by 5,9-8,8 mm. The most important summer period for the growth and development of cultivated plants was characterized by a decrease in precipitation: in Bredy by $50,8 \mathrm{~mm}$, in Zlatoust by $41,4 \mathrm{~mm}$, in Troitsk by $17,1 \mathrm{~mm}$, in Kurgan by $15,8 \mathrm{~mm}$, in Yekaterinburg by $8,2 \mathrm{~mm}$. A significant increase in the sum of summer precipitation was noted only in Shadrinsk by $22,1 \mathrm{~mm}$.

4. Favorable changes in the agro-climatic conditions of the growing season were noted in Shadrinsk (where the hydrothermal coefficient increased from 1,18 to 1,26) and in Zlatoust (where the growing season ceased to be excessively humid and HTC decreased from 2,29 to 1,79). A deterioration of conditions for cultivated plants and decreased HTC is noted in Chelyabinsk by 0,12 , in Kurgan by 0,14 , in Troitsk by 0,17 , in Yekaterinburg by 0,20 and in Bredy by 0,25 .

5. Climate change at the Urals requires agricultural science to create new varieties of plants with a higher adaptive potential, to develop scientifically grounded zonal farming systems, to increase the resistance of cultivated plants to abiotic and biotic stresses. The development of adaptive cultivation technologies and an irrigation system for the southern regions of the Urals is urgent.

\section{References}

1. A.L. Ivanov, Agriculture, 1, 3 (2009)

2. R. Maiti, H. G. Rodriguez, N. S Ivanova, Autoecology and Ecophysiology of Woody Shrubs and Trees: Concepts and Applications, 352 (2016)

3. L.V. Shaikhulmardanova, V.V. Guryanov, Yu.P Perevedentsev, Scientific notes of Kazan University, Series Natural Sciences, 160(3), 531(2018)

4. B.N. Porfiryev, V.M. Kattsov, S.A. Roginko, Climate change and international security, 290 (2011)

5. E.P. Kvachantiradze, S.I. Terekhova, The International Technical-Economic Journal, 6, 133 (2018)

6. L.S Fedotova, Potatoes and vegetables, 8, 6 (2008)

7. D. Milicevic, B. Lakicevic, R. Petronijevic, Z. Petrovic, J. Jovanovic, S. Stefanovic, S. Jankovic, Theory and Practice of Meat Processing, 4(1), 9 (2019)

8. A.S. Zeynalov, Successes of modern science, 9, 94 (2017)

9. O.B. Tkachenko, Mikology and phytopathology, 52(6), 382 (2018)

10. G. Gelybó, E. Tóth, C. Farkas, Á. Horel, I. Kása, Z. Bakacsi, Agrokemia es Talajtan, 67(1), 121 (2018)

11. A.I. Belolyubtsev, E.A. Dronova, Environmental management, 5, 75 (2018)

12. A.A. Konishchev, E.N. Konishcheva, Agrarian journal of Upper Volga region, 3, 18 (2018)

13. G.R. Safina, V.N. Golosov, Proceedings of Kazan University, Natural Sciences Series, 160, $111(2018)$

14. E.I. Koshkin, I.V. Andreeva, G.G. Guseinov, Agrochemistry, 12, 83 (2019)

15. L.S. Fedotova, A.V. Kravchenko, Potatoes and vegetables, 2, 20 (2011)

16. N.N. Yashalova, D.A. Ruban, Regional Economics: Theory and Practice, 16(6), 1127 (2018)

A. Kucher Agricultural and Resource Economics: International Scientific E-Journal, 3(1), 119 (2017) 
17. M. Prokopová, L. Salvati, O. Cudlín, R. Včeláková, R. Plch, P. Cudlín, G. Egidi, Sustainability, 11(17), 4654 (2019)

18. S.V. Zelentsov, E.V. Moshnenko, Scientific Dialogue, 7, 40 (2012)

19. O.N. Bulygina, V.N. Razuvaev, L.T. Trofimenko, N.V. Shvets, http://meteo.ru/

20. O.N. Bulygina, V.N. Razuvaev, N.N. Korshunova, N.V. Shvets, http://meteo.ru/

21. N.A. Polev, V.V. Yurashev, I.S. Shatilov, A.G., Zamaraev, Agrochemical Bulletin, 1, $34(2001)$ 